\title{
STUDIES ON NORTH AMERICAN CARBONIFEROUS INSECTS. 9. A NEW SPECIES OF EUBLEPTIDAE FROM MAZON CREEK (PALAEODICTYOPTERA)
}

\author{
By Frank M. CARPENTER \\ Museum of Comparative Zoology \\ Harvard University, Cambridge, Mass. 02138
}

In a previous part of this series (Carpenter, 1983) I discussed the structure and relationships of the extinct family Eubleptidae and its unique generic representative, Eubleptus danielsi Handlirsch. This was based on my study of the 17 specimens of the insect then known, all from the Upper Carboniferous of Mazon Creek, Illinois. Since then, Mr. Michael A. Madsen, of Darien, Illinois, has kindly loaned me for study a well-preserved specimen of a new species also belonging to Eubleptus. Since this contributes considerably to our understanding of the family, I am describing it here.

Family Eubleptidae Handlirsch, 1906

Eubleptus maculosus n. sp.

Figures 1-4

This species is similar to danielsi, so far as known. Both species have the same basic pattern of venation in fore and hind wings, but in maculosus the wings are more slender and the points of origin of RS and of the forking of $M$ are much nearer the center line of the wings. Also, MA in both fore and hind wings is unbranched in maculosus but deeply forked in danielsi. Of special interest is the presence of four large, dark, submarginal spots extending to midwing in both fore and hind wings of maculosus, in addition to certain other spots along other main veins. In danielsi both wings have four dark spots on the anterior margins, but none on the rest of the wings.

Very little of the body is preserved. The abdomen is $11.5 \mathrm{~mm}$. long and $1.5 \mathrm{~mm}$. wide; the cerci, which are very prominent in

Manuscript received 30 July 1992. 


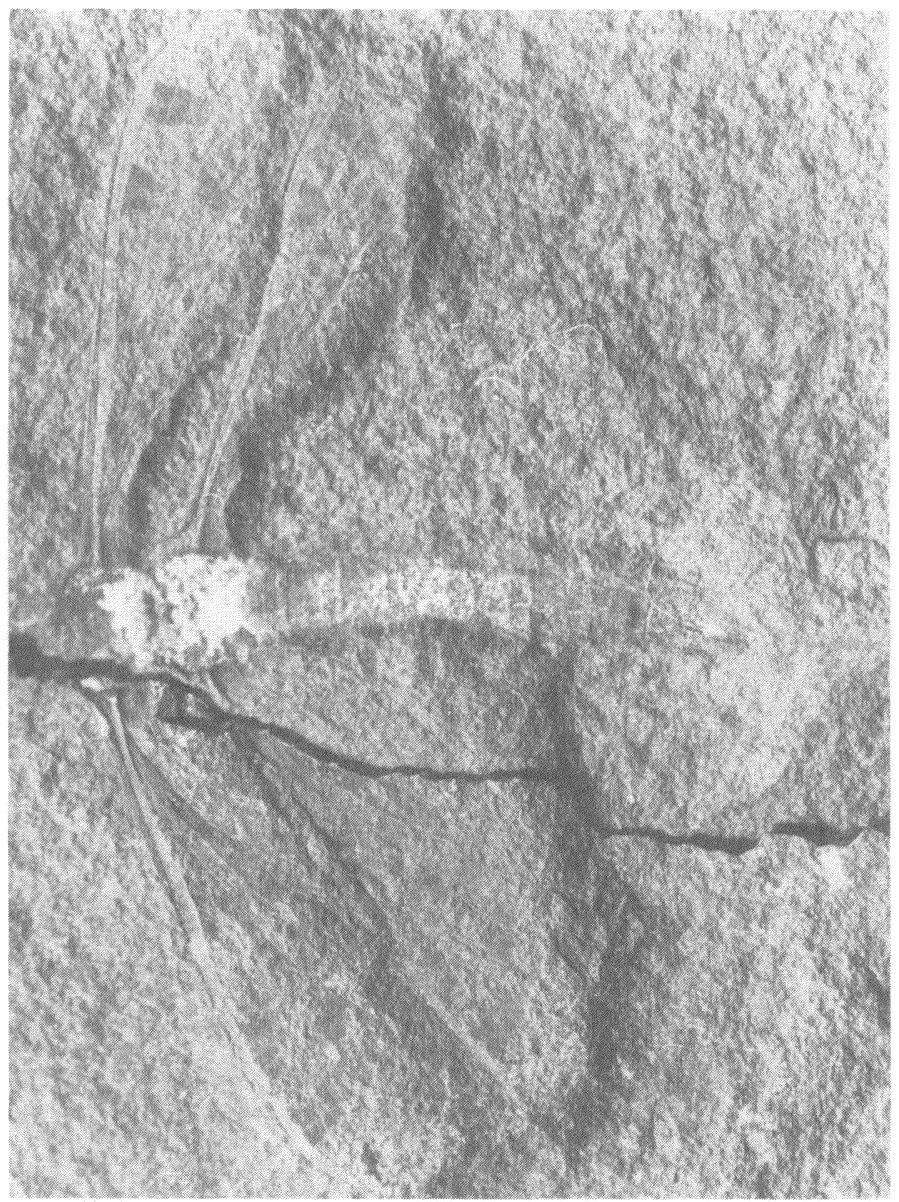

Figure 1. Eubleptus maculosus, n. sp. Dorsal view of type specimen, obverse half. Wing expanse, $32 \mathrm{~mm}$.

danielsi, are not clearly preserved in maculosus, and the head is not preserved at all. The fore and hind wings are $14 \mathrm{~mm}$. long.

Holotype: in the collection of Michael A. Madsen, Darien, Illinois. The fossil was collected by him at Mazon Creek, Pit 11, Braidwood, Illinois (Upper Carboniferous), and includes both counterparts. 


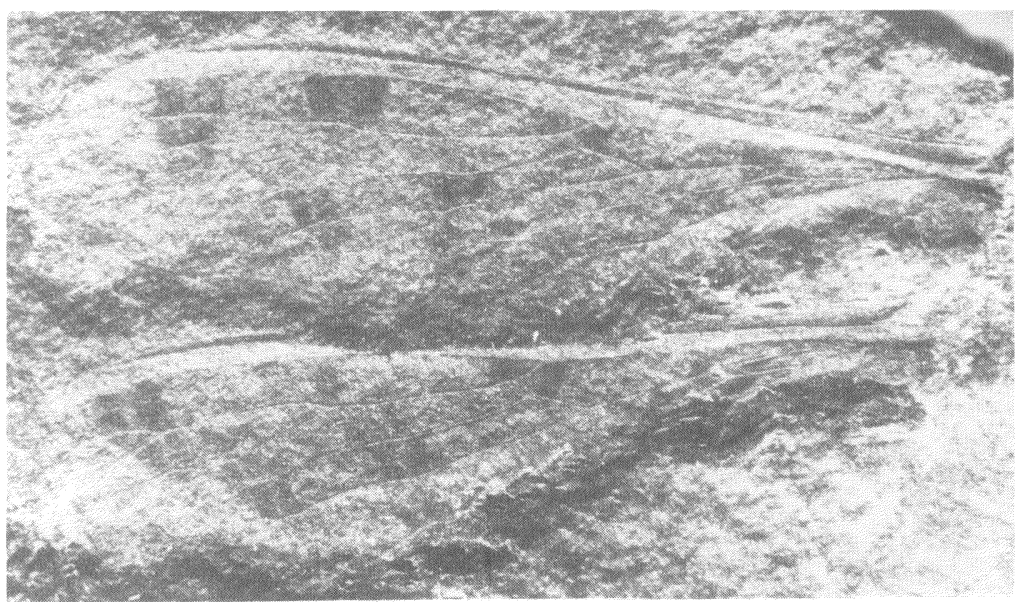

Figure 2. Eubleptus maculosus, n.sp. (type), showing dark spots.

The family Eubleptidae was proposed by Handlirsch in 1906 for a single, fragmented specimen of a new species, Eubleptus danielsi, from the Upper Carboniferous of Mazon Creek, Illinois. As noted by Handlirsch, this was the smallest Carboniferous insect known, and it still stands as one of the smallest pterygote insects found in Paleozoic deposits. Handlirsch placed the family in the order Palaeodictyoptera, although the fragmentary nature of the fossil gave little evidence of its phylogenetic position. In 1911 Handlirsch added another new genus and species (Athymodictya parva from Mazon Creek) to the family, but that has subsequently been shown to be a synonym of danielsi (Carpenter, 1983).

The systematic position of the family Eubleptidae has been doubtful for many years. Martynov mentioned his uncertainty about its ordinal position in 1938, and Laurentiaux in 1953 placed the family in a new order, Eubleptidia, but without giving a definition of the order. Rohdendorf accepted that order in 1962, although he changed the name to Eubleptodia. A few years later (1965), following my examination of the two previously mentioned specimens, I concluded that the insects were most like the members of the order Palaeodictyoptera as Handlirsch thought. In 1983 I was 


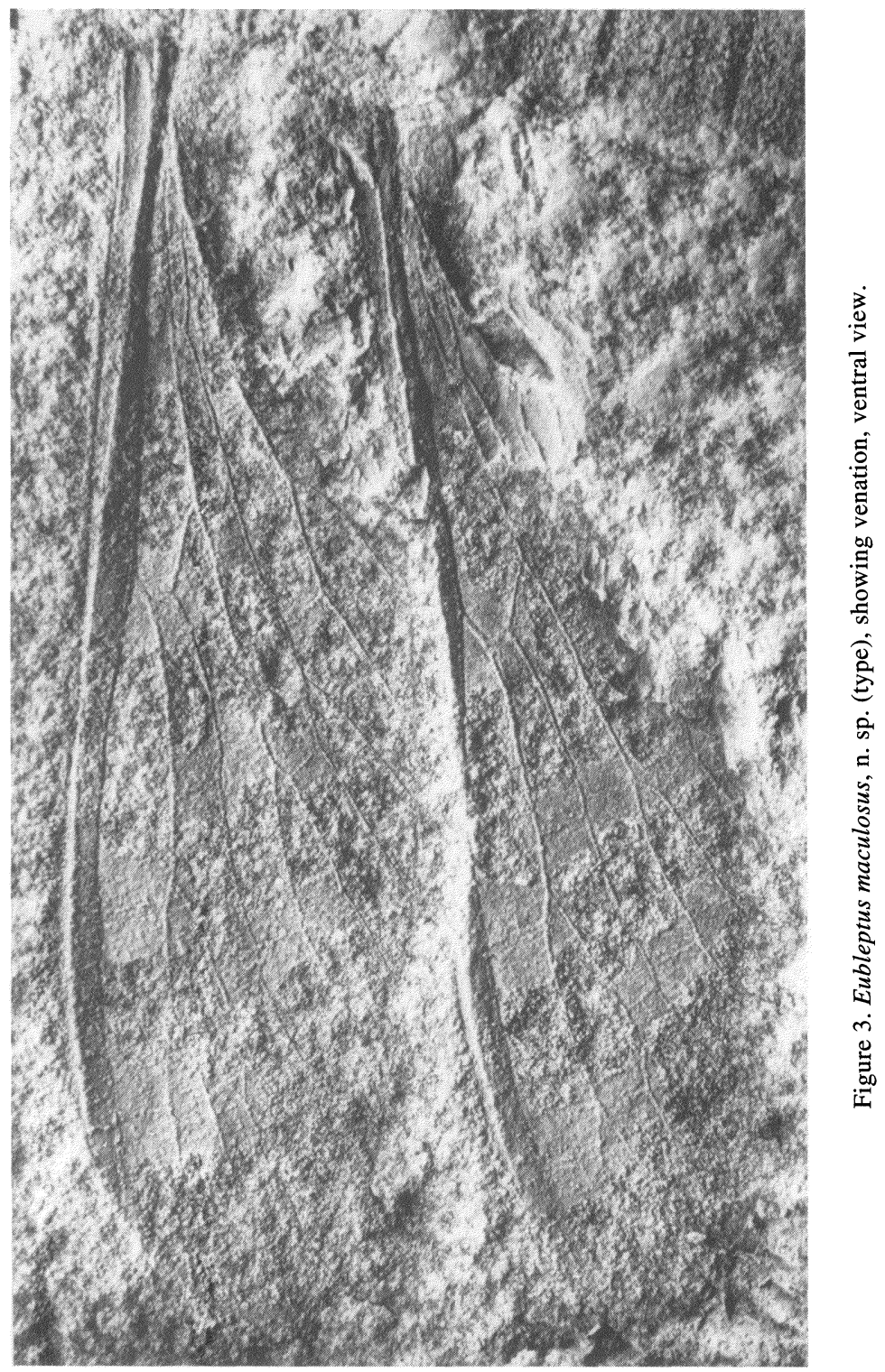




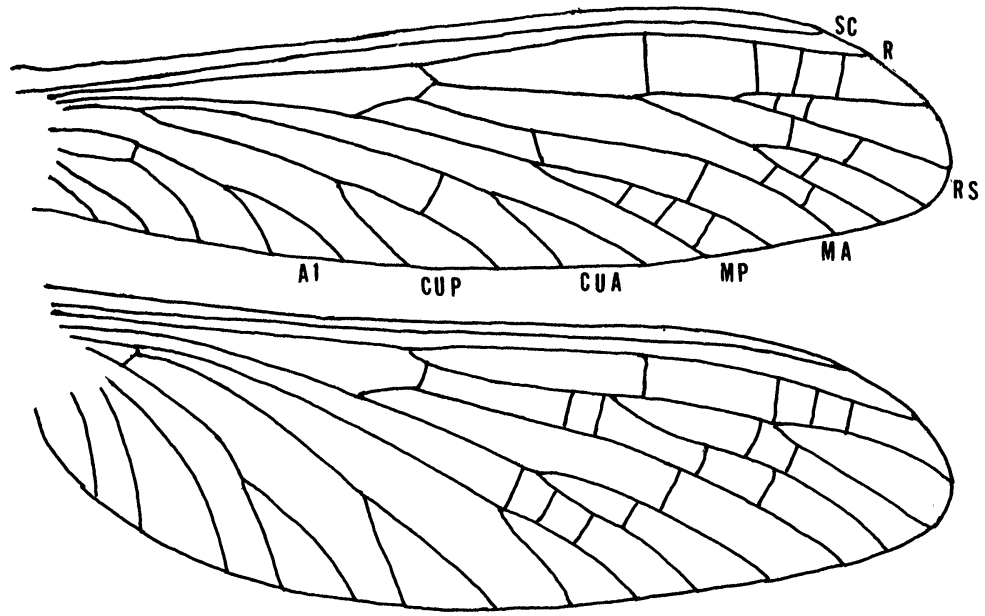

Figure 4. Eubleptus maculosus, n. sp. (type). Venational diagram of fore and hind wings.

able to study 17 recently collected specimens of danielsi from Mazon Creek, most of which had been found by private collectors. Many of the fossils were very well preserved. From my study of them I concluded that the new evidence supported Handlirsch's original assumption that they belonged to the order Palaeodictyoptera, and were, in fact, close relatives of the family Spilapteridae (Carpenter, 1983). The structure of the new species, maculosus, supports that conclusion.

\section{Literature Cited}

\section{CARPenter, F. M.}

1965. Studies on North American Carboniferous insects. 4. The genera Metropator, Eubleptus, Hapaloptera, and Hadentomum. (Palaeodictyoptera). Psyche, 72: 175-190.

1983. Studies on North American Carboniferous insects. 7. The structure and relationships of Eubleptus danielsi (Palaeodictyoptera). Psyche, 90: 81-95. 


\section{HANDLIRSCH, ANTON}

1906a. Revision of American Palaeozoic insects. Proceedings of the U.S. National Museum, 29: 661-820.

1906b. Die fossilen Insekten und die Phylogenie der rezenten Formen. Ein Handbuch für Paläontologen un Zoologen. Engelmann, Leipsig. p. $1-640$.

1911. New Paleozoic insects from the vicinity of Mazon Creek, Illinois. American Journal of Science (4) 21: 297-326, 353-377.

LAURENTIAUX, D.

1953. Classe des insectes. In Traité de Paleontologie (ed., Piveteau), p. 397-527.

MARTYNOV, A. V.

1938. Études sur 1'histoire geologique et de phylogenie des ordres des insects. Trudy paleontologicheskogo instituta academii nauk SSSR, 7: $1-150$.

ROHDENDORF, B. B.

1962. Osnovy Palaeontologii: Tracheata, Mandibulata. Akad. Nauk., USSR, p. 1-374. 

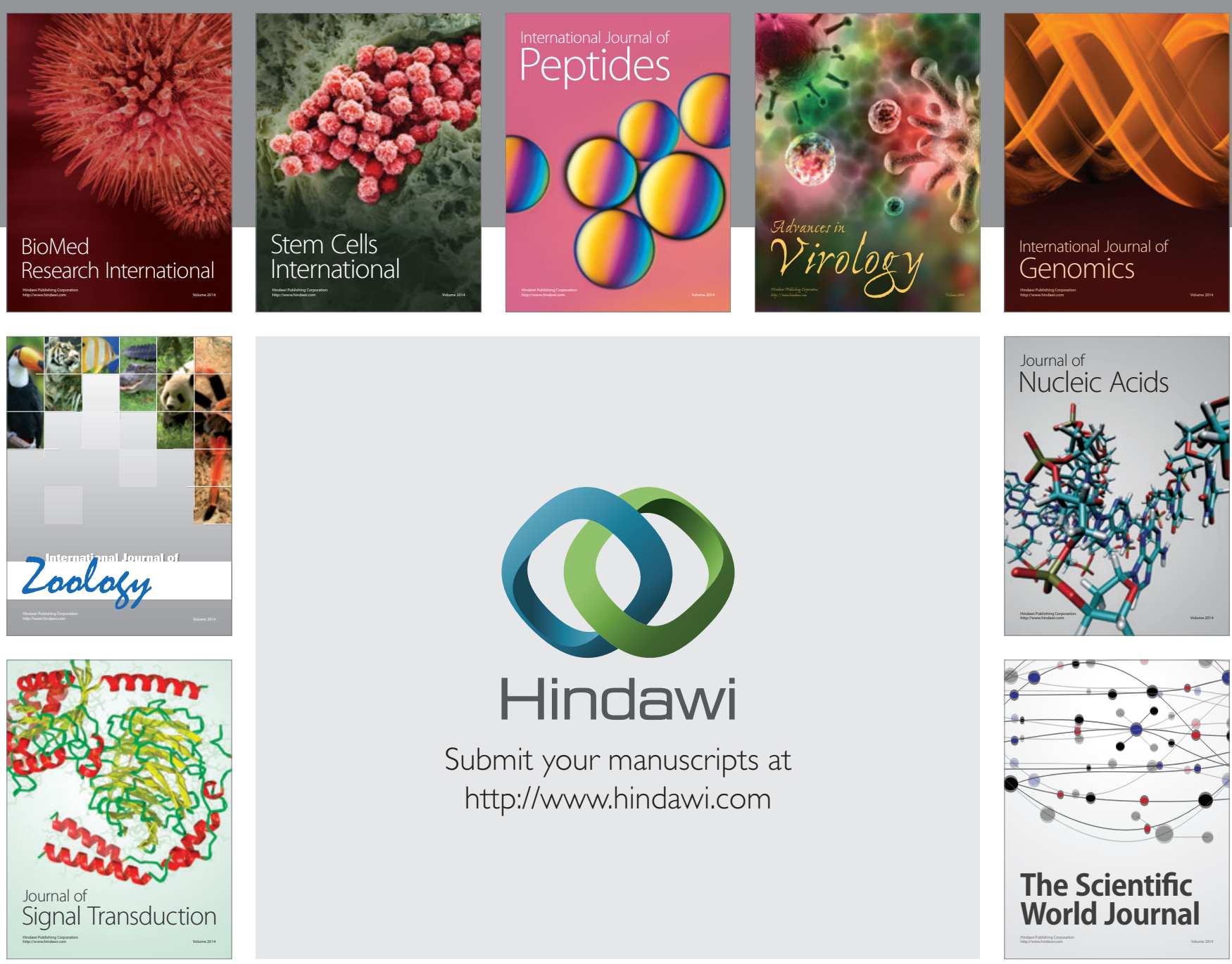

Submit your manuscripts at

http://www.hindawi.com
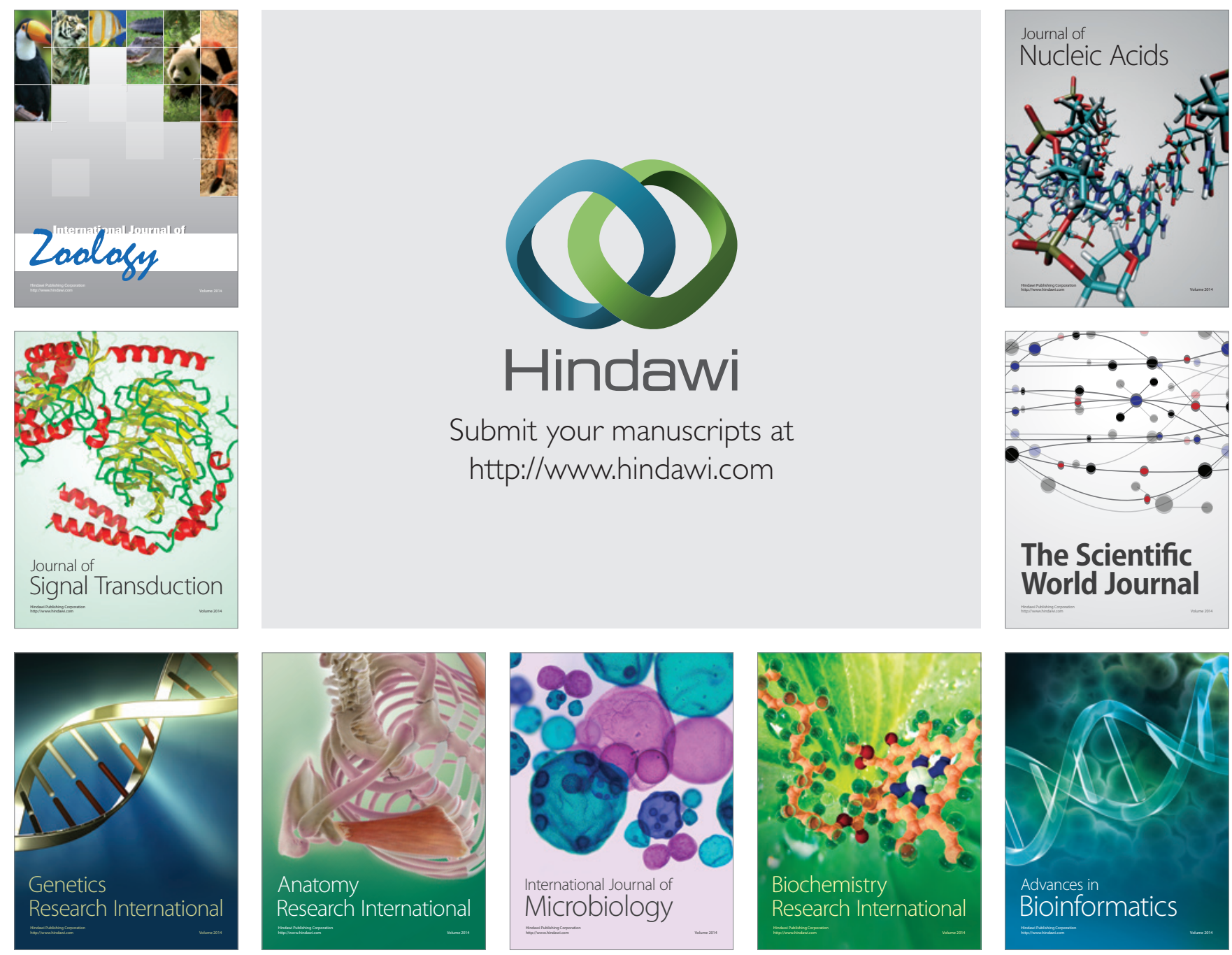

The Scientific World Journal
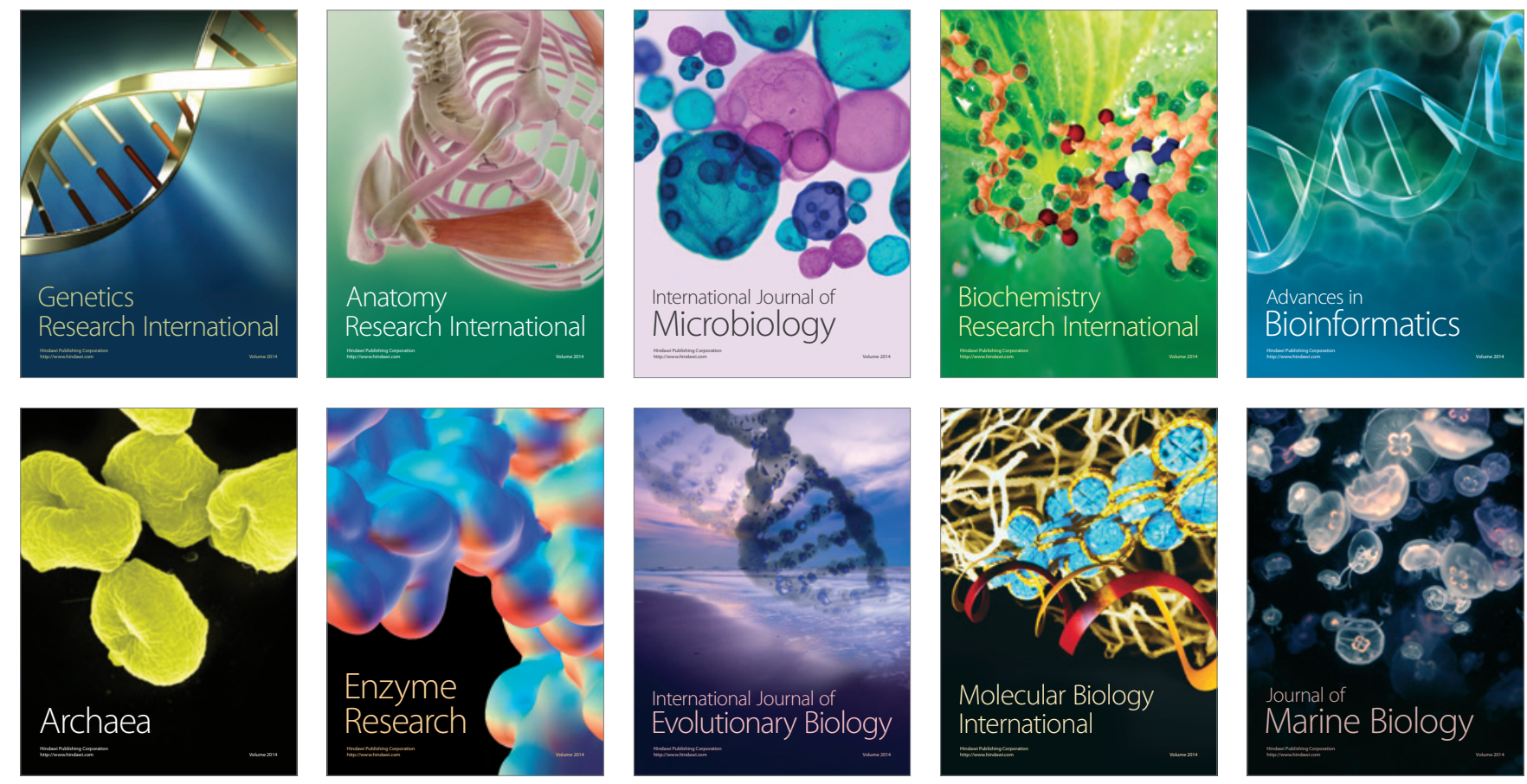